\title{
THE SIGNIFICANCE OF BLUE POLYCHROMASIA
}

\author{
BY \\ E. DAVIDSON \\ From Groote Schuur Hospital, University of Capetown*
}

(RECEIVED FOR PUBLICATION JULY 12, 1958)

The standard references and textbooks comment on the spectrum of colours, from grey to blue, seen in the polychromasic erythrocytes. The significance attached to these cells varies, and the general attitude is summarized by Wintrobe (1956) in the following statement:

"Macrocytes, and to a lesser extent polychromatophilia, are like reticulocytes, manifestations of orderly and probably efficient new blood formation."

The present study suggests that the significance of polychromatophilia is in part determined by the colour of the polychromasic cell.

\section{Materials and Methods}

As the polychromasic cells (Key, 1921; Rodan, 1949) and nucleated red cells (Stein, 1948; Rodan, 1949) collect in the buffy layer, a blind study was carried out on the buffy layer from 95 patients, including 11 children under the age of 6 years. A total of 137 slides (no more than two from each patient) was examined. With one exception (an iron deficiency anaemia) all slides examined represented the morphology of the red cells before treatment.

The buffy layer was lifted with a Pasteur pipette from the standard haematocrit tubes. The contents of the pipette was divided between two slides and the excess plasma and red cells drained off with a piece of blotting paper placed at the edge of the drop. In draining the drop to almost complete dryness, the small grey-white granules of buffy material were left adherent to the glass slide. Smears made from these granules were stained with May-Grünwald Giemsa stain (Dacie, 1956).

The characteristics-blue polychromasia, grey polychromasia, and nucleated red cells-were estimated independently using the following scale:

Trace $(\mathrm{Tr})=$ occasional cells only. $+=$ occasional cells in every oil-immersion field. $++=$ few cells in each field.

$+++=$ cells in $25 \%$ of each field.

Reticulocyte counts were carried out using 1\% brilliant cresyl blue in saline (Dacie, 1956). A total of 2,000 cells was counted in each slide.

* Present address : Department of Medicine, Tennis Court Road, Cambridge.

\section{Results}

The quantitative assessment of grey and blue polychromasia is presented in Table $\mathrm{I}$.

TABLE I

ASSESSMENT OF GREY AND BLUE POLYCHROMASIA

\begin{tabular}{|c|c|c|c|c|c|c|c|}
\hline $\begin{array}{c}\text { Number } \\
\text { of } \\
\text { Slides }\end{array}$ & $\begin{array}{c}\text { Megalo- } \\
\text { blastic } \\
\text { Anae- } \\
\text { mia }\end{array}$ & $\begin{array}{c}\text { Haem- } \\
\text { olytic } \\
\text { Anae- } \\
\text { mia }\end{array}$ & $\begin{array}{c}\text { Myelo- } \\
\text { phthisic } \\
\text { Anae- } \\
\text { mia }\end{array}$ & $\begin{array}{c}\text { Fe De- } \\
\text { ficiency } \\
\text { Anae- } \\
\text { mia }\end{array}$ & $\begin{array}{l}\text { Throm- } \\
\text { bocyto- } \\
\text { penia }\end{array}$ & Normal & $\begin{array}{l}\text { Miscel- } \\
\text { laneous }\end{array}$ \\
\hline
\end{tabular}

Polychromasia "Grey"

\begin{tabular}{|c|c|c|c|c|c|c|c|}
\hline \multicolumn{8}{|c|}{ O Gigcinginasia } \\
\hline 0 & 6 & 3 & 8 & 2 & 9 & 9 & 9 \\
\hline $\begin{array}{c}+ \\
++ \\
++\end{array}$ & $\begin{array}{r}14 \\
8 \\
4\end{array}$ & $\begin{array}{r}11 \\
4 \\
4\end{array}$ & $\begin{array}{r}10 \\
3 \\
2\end{array}$ & $\begin{array}{r}10 \\
0 \\
0\end{array}$ & $\begin{array}{l}1 \\
2 \\
1\end{array}$ & $\begin{array}{l}4 \\
0 \\
0\end{array}$ & $\begin{array}{l}3 \\
0 \\
2\end{array}$ \\
\hline
\end{tabular}

\begin{tabular}{c|r|r|r|r|r|r|r}
\multicolumn{8}{c}{ Polychromasia " Blue " } \\
0 & 9 & 18 & 16 & 11 & 10 & 13 & 11 \\
$\operatorname{Tr}$ & 4 & 0 & 1 & 1 & 1 & 0 & 1 \\
+ & 11 & 2 & 2 & 0 & 2 & 0 & 0 \\
++ & 4 & 1 & 3 & 0 & 0 & 0 & 1 \\
+++ & 4 & 1 & 1 & 0 & 0 & 0 & 1 \\
\hline
\end{tabular}

Bold figures $=$ children.

Polychromasia Grey.-One plus polychromasia was found in the buffy layer of normal individuals. More than one plus was found in all other groups with the exception of the irondeficiency anaemias. Patients exceeding one plus in the thrombocytopenic and miscellaneous group were all children. Thus in the adult more than one plus grey polychromasia was found in the megaloblastic, myelophthisic, and haemolytic anaemias.

Polychromasia Blue. - Blue polychromasia was not found in the buffy layer of normal individuals. In the iron-deficiency anaemias a single blue polychromasic cell was found in the buffy layer of a patient receiving iron therapy. In the thrombocytopenic and haemolytic groups these cells were found in children only. Thus in the adult more than a trace of blue polychromasia was found in the megaloblastic, myelophthisic anaemias as well as in a patient suffering from an aplastic anaemia (miscellaneous group).

There appears to be a direct relationship between the reticulocyte count and grey 


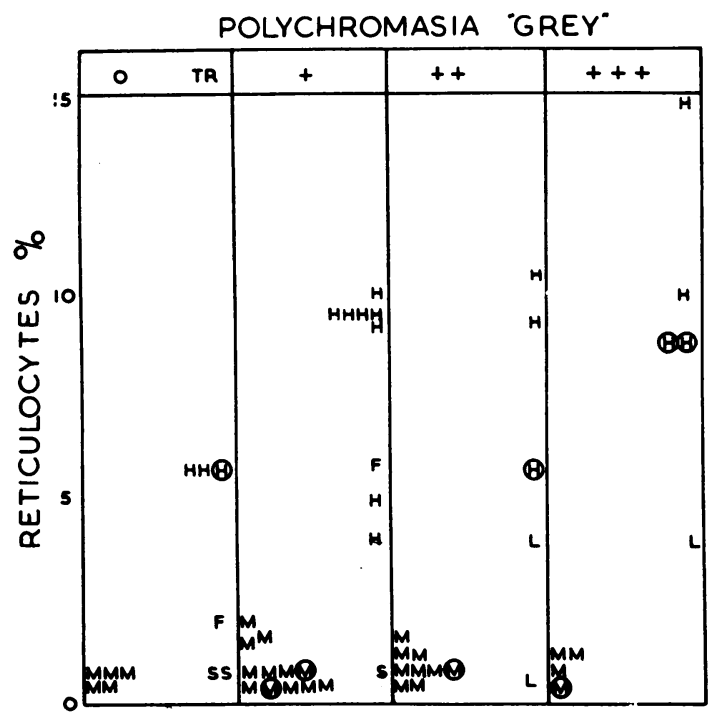

Fig. 1

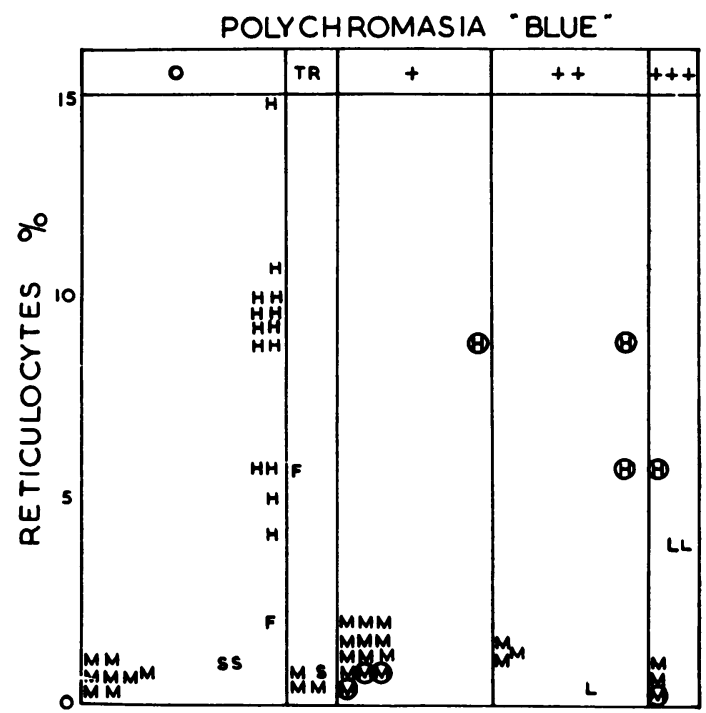

Fig. 2

POLYCHROMASIA "BLUE"

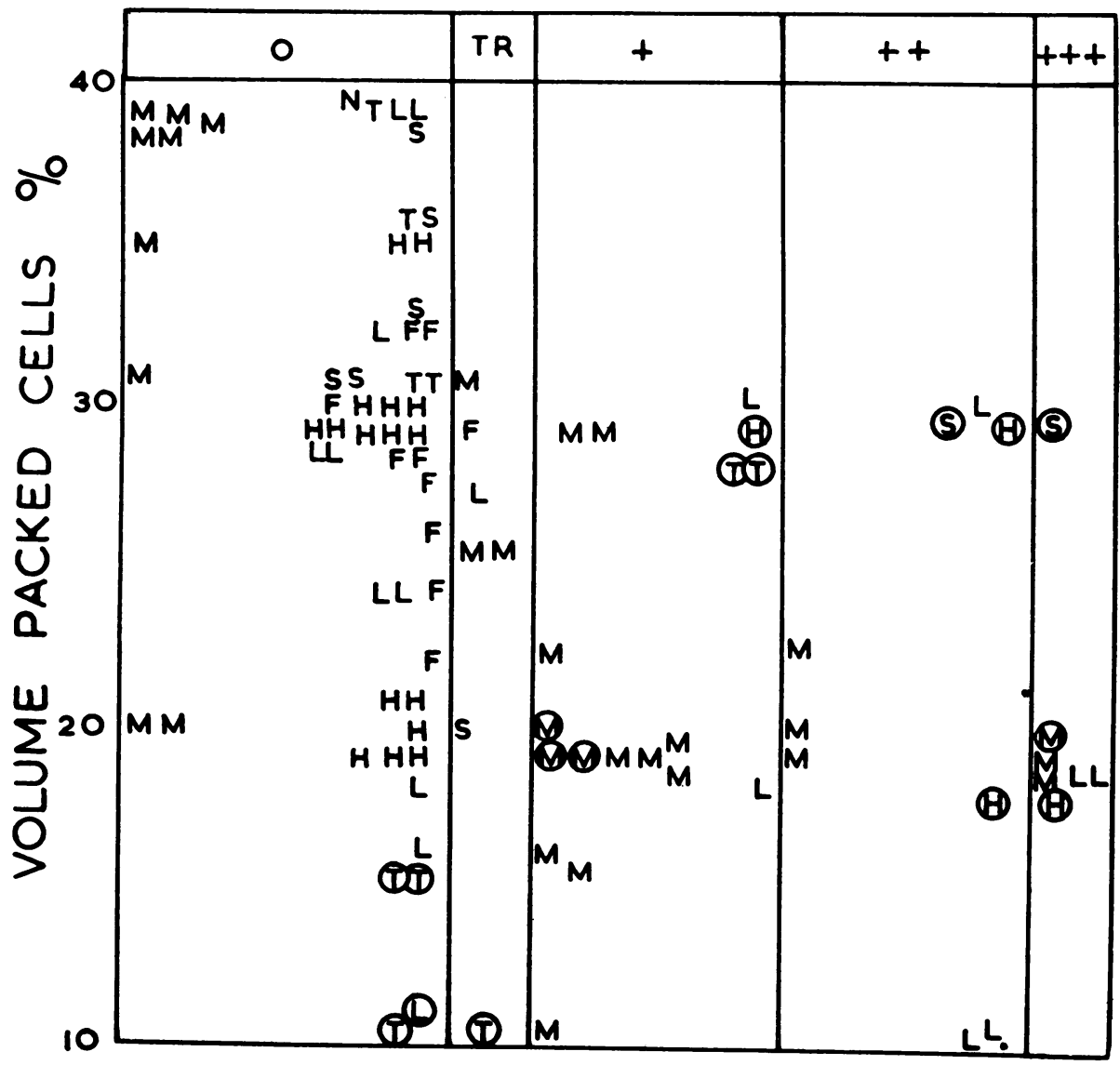

Fis. 3

H-Haemolytic anaemia. M-Megaloblastic anaemia. F-Iron-deficiency anaemia. T-Idiopathic thrombocytopenic purpura. L-Myelophthisic anaemia. S-Miscellaneous group. Encircled letters-children. N-Normal. 


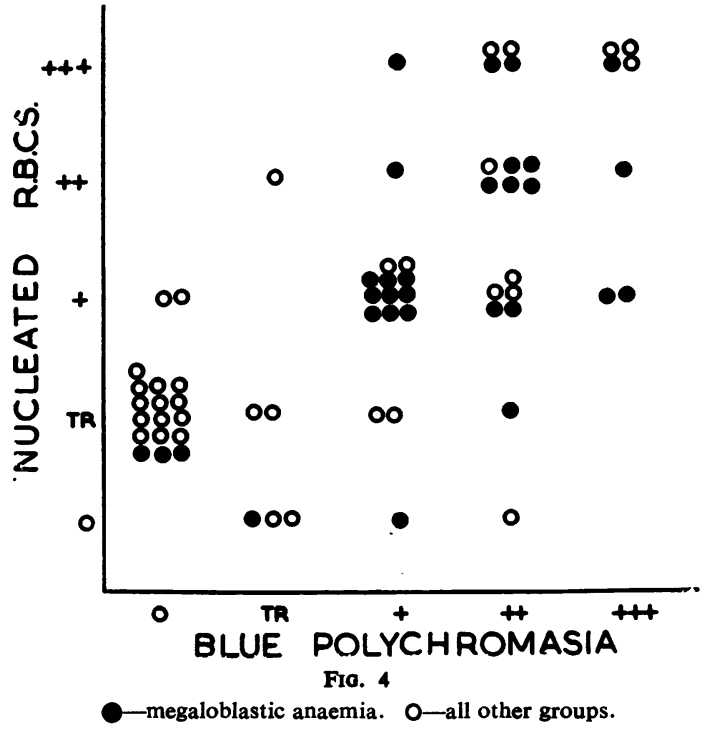

polychromasia in the haemolytic anaemias (Fig. 1).

In the adult there appears to be an inverse relationship between blue polychromasia and the reticulocyte count (Fig. 2).

In the megaloblastic group the incidence of blue polychromasia is related to the severity of the anaemia (Fig. 3).

There appears to be a direct relationship between the incidence of blue polychromasic cells and the nucleated red cells (Fig. 4).

\section{Discussion}

The basophilic material in the polychromasic cell is a ribonucleoprotein (Haenel, 1949) which on contact with brilliant cresyl blue is precipitated into the filamentous flakes seen in the reticulocyte (Orten, 1934). The present study suggests that when blue polychromasia is present in the adult, then a low reticulocyte count can be anticipated and a serious disturbance of haemopoiesis suspected in the form of a megaloblastic, myelophthisic, or aplastic anaemia. Although the division between grey and blue polychromasia is vague repeated observations on the same slide indicate that blue polychromasia can be identified and estimated fairly accurately.

The relationship between polychromasia and reticulocytosis can be briefly summarized. In the normal person with a reticulocyte count ranging from 0.2 to $2 \%$ only an occasional grey polychromasic cell is seen in the peripheral blood. With the response to haemolysis and haemorrhage there is an increase in the reticulocyte count (R) and the number of polychromasic cells $(P)$. In the adult the latter cells are confined to the grey type, whereas in the child and infant large numbers of the blue type may also be found. This orderly regenerative response is associated with a slight increase in the $P / R$ ratio.

When erythropoiesis is profoundly disturbed, as in the megaloblastic, myelophthisic and aplastic anaemias, there is an increase in the number of polychromasic cells without a corresponding rise in the reticulocyte count and the $P / R$ ratio rises markedly. In the adult this is associated with the appearance of blue polychromasic cells in the peripheral blood.

Dacie (1954) comments on the fact that large numbers of normoblasts in the peripheral blood (except in young children) "should cause the observer to reconsider the diagnosis of primary haemolytic anaemia." The correlation between blue polychromasia and the nucleated red cells suggests that a similar significance should be attached to the presence of blue polychromasia.

\section{Summary}

It is suggested that there is a difference in the significance of grey and blue polychromasia in the adult peripheral blood and that the latter cell suggests a serious disturbance of haemopoiesis in the form of a megaloblastic, myelophthisic, or aplastic anaemia.

\section{REFERENCES}

Dacie, J. V. (1954). The Haemolytic Anaemias. J. \& A. Churchill, London.

(1956). Practical Haematology. J. \& A. Churchill, London.

Haenel, U. (1949). Acta Haemat. (Basel), $2,298$.

Key, J. A. (1921). Arch. intern. Med., 28, 511.

Orten, J. M. (1934). Yale J. biol. Med., 6, 519.

Rodan, K. S. (1949). J. clin. Path., 2, 232.

Stein, H. (1948). Personal communication.

Wintrobe, M. M. (1956). Clinical Hematology, 4th ed. Lea \& Febiger Philadelphia. 